\title{
Lead accumulation and elimination in tissues of Prussian carp, Carassius gibelio (Bloch, 1782), after long-term dietary exposure, and depuration periods
}

\author{
Ewa Luszczek-Trojnar • Ewa Drąg-Kozak • Włodzimierz Popek
}

Received: 31 May 2012 / Accepted: 17 September 2012 / Published online: 6 October 2012

(C) The Author(s) 2012. This article is published with open access at Springerlink.com

\begin{abstract}
We studied the bioaccumulation of lead in selected tissues of Prussian carp Carassius gibelio (Bloch, 1782) during 12 and 24 months exposure to different doses of this metal in feed and the elimination of lead from tissues during the following 12-month depuration period. Lead concentration was determined using atomic absorption spectrometry method. The highest lead concentrations were observed at $2.0 \pm$ 0.54 to $7.4 \pm 1.1 \mathrm{mgkg}^{-1}$ in the kidney, $3.0 \pm 0.13$ to $5.2 \pm$ $0.17 \mathrm{mgkg}^{-1}$ in the bone, and $4.5( \pm 0.4) \mathrm{mg} \mathrm{kg}^{-1}$ in the hepatopancreas of fish from groups exposed to lead dietary concentration from 8 to $49 \mathrm{mgkg}^{-1}$ for 24 months. The rate of accumulation were generally the highest at the beginning of exposure as evidenced by the highest monthly increments of bioaccumulation observed after 3 months of contamination for muscles, hepatopancreatic gland, intestine, and gills. Also analysis of the monthly increments of lead bioaccumulation in bone tissue and the highly significant coefficients of correlation indicate that the dynamics of accumulation are clearly dependent on dose of exposure. Depuration of accumulated lead from the organs depended mainly on tissue and duration of elimination period. Very rapid depuration was observed in soft tissues such as the intestine or muscles. Very low elimination was observed for scales and bones where until the end of the experiment highly significant lead concentration differences were observed in all groups in relation to the control group.
\end{abstract}

Responsible editor: Vera Slaveykova

Electronic supplementary material The online version of this article (doi:10.1007/s11356-012-1210-8) contains supplementary material, which is available to authorized users.

E. Łuszczek-Trojnar $(\triangle) \cdot$ E. Drag-Kozak $\cdot$ W. Popek

Department of Ichthyobiology and Fisheries,

University of Agriculture in Krakow,

Spiczakowa 6,

30-199 Kraków-Mydlniki, Poland

e-mail: e.trojnar@ur.krakow.pl
Chronic dietary exposure in the range of $8-49 \mathrm{mg} \mathrm{Pbkg}^{-1}$ resulted in no significant effects on the growth and survival of Prussian carp females.

Keywords Prussian carp $\cdot$ Dietary $\cdot$ Lead $\cdot$ Exposure . Accumulation $\cdot$ Depuration

\section{Introduction}

Lead belongs to a group of toxic metals which have no function in the physiological processes of living organisms (Adeyeye et al. 1996). Limit values of lead according to Polish standards average $7.2 \mu \mathrm{gl}^{-1}$ for surface waters (Journal of Laws 2011) and $200 \mathrm{mgkg}^{-1}$ for bottom sediments (Journal of Laws 2002). Reports from 2009 for the largest Polish river, the Vistula, and its tributaries, showed that despite the fact that lead levels in water were not exceeded, high concentrations of this metal (in excess of $1,800 \mathrm{mgkg}^{-1}$ ) were observed in bottom sediments (GIOS 2010). It is well known that this metal easily accumulates in fish tissues such as bones, gills, kidneys, liver, and scales (Dallas and Day 1993). Because lead crosses the blood-brain barrier, it can cause various detrimental effects to the body condition, health, and life of fish (Hodson et al. 1978; Needleman and Bellinger 1991; Rabitto et al. 2005). Bioaccumulation of lead in piscine tissues is a threat to humans who may absorb considerable amounts of this metal from contaminated fish. It is common knowledge that lead adversely affects the intellectual development of children, increases arterial pressure, and contributes to cardiovascular diseases in adults (EC 2001). Therefore, the importance of studies of lead bioaccumulation in fish, which represent a valuable source of food for humans, in the context of environmental pollution, seems unquestionable. Heavy metals enter the body of fish through the skin or gills via the dissolved phase and through the digestive tract via the food 
(Pourang 1995; Vincent et al. 2002; Sarnowski 2003). Because waters generally have low lead levels, even when high concentrations are found on the bottom, food is a significant source of these elements for fish (Javed and Hayat 1996; Clearwater et al. 2000). Therefore, the aim of the present study was to investigate the bioaccumulation of lead in selected tissues of Prussian carp during long-term exposure (12 and 24 months) to different doses of this metal in feed and the elimination of lead from tissues during the following 12month depuration period.

The distribution of metals $(\mathrm{Hg}, \mathrm{Cd}, \mathrm{Pb}, \mathrm{Cr}, \mathrm{Cu}, \mathrm{Zn}, \mathrm{Ni}, \mathrm{Fe}$, and $\mathrm{Mn}$ ) in the tissues of different fish species such as perch, roach, chub, white bream, smelt, grayling, or pike was described previously, with fish used as bioindicators of water pollution (Spurný et al. 2002; Staniskiene et al. 2006). The Prussian carp was chosen as an experimental model due to its low sensitivity and high resistance to adverse environmental conditions. The Prussian carp is an important subject for model experiments involving heavy metals, biomonitoring, and industrial and amateur fishing (Syasina et al. 2012). This species is widely distributed in Europe, Siberia, and Asia; in the eastern regions, it is represented by bisexual populations with single monosex polyploid populations (Fan and Liu 1990). Most European populations are monosex populations, living as triploid females that reproduce gynogenetically (Boroń et al. 2011), and such a population was chosen for this study to eliminate the effect of sex on the accumulation or elimination of lead during the experiment.

The dietary lead levels to which Prussian carp were exposed in the present experiment were based on the reported concentrations of this metal in benthic organisms that are the Prussian carp's natural food, which may range from 0 to as much as $792 \mu \mathrm{gPbg}^{-1}$ dry weight (dw; Hodson et al. 1978; Woodward et al. 1994). Given that the study was aimed to show the effect of long-term exposure (the normal level of lead in invertebrates in an unpolluted environment should not exceed $1 \mu^{-1} g^{-1}$ (Farag et al. 1999)), we chose concentrations simulating the average degree of environmental contamination $\left(8,13,24\right.$, and $\left.49 \mathrm{mgkg}^{-1}\right)$ to find out if their constant presence in fish diets will significantly affect the bioaccumulation and subsequent elimination of lead from Prussian carp tissues, and whether the bioaccumulation will vary according to the dose of exposure. An attempt was also made to observe the dynamics of the bioaccumulation and elimination processes depending on duration of exposure and depuration.

\section{Materials and methods}

Fish and diet

Used in the study are 420 female Prussian carps Carassius gibelio (Bloch, 1782), originating from "Górki" Fish Farm in Wiślica, Poland. Fish were stocked in fourteen 3001 aquaria (30 fish per aquarium) at water supplied from the Municipal Waterworks in Cracow, an average temperature of $17{ }^{\circ} \mathrm{C}$, $\mathrm{pH}$ of 7.7 , dissolved oxygen of $10.5 \mathrm{mgl}^{-1}$, and water hardness of $127 \mathrm{mg} \mathrm{CaCO}_{3} \mathrm{l}^{-1}$. In addition, the water was aerated and filtered. The experiment was preceded by a 4-month adaptation period when fish were fed a control diet (lead concentration of $0.1 \mathrm{mgkg}^{-1} \mathrm{dw}$ ). Exposure to lead began when fish were 9 months old, had an average body weight of $20 \mathrm{~g}$ and body length of $10 \mathrm{~cm}$. Fish were divided into five groups which were fed control pellets (group 1) and pellets contaminated with different concentrations of lead $\left(8,13,24\right.$, and $49 \mathrm{mg} \mathrm{Pbkg}^{-1}$ _ groups 2-5) for two exposure periods of 12 and 24 months (Table 1). Pellets of complete feed for Prussian carp were produced by the Institute of Ichthyobiology and Aquaculture of the Polish Academy of Sciences in Gołysz using the components: grains, oilseed, fish meal, and vitamin and mineral supplements. Specifications for the fodder were $37 \%$ crude protein, $12 \%$ crude fat, and $31 \%$ carbohydrates. Control and experimental pellets were prepared the same way, but there were no $\mathrm{Pb}$ addition into the control fodder. Lead acetate trihydrate $\mathrm{Pb}$ $\left(\mathrm{CH}_{3} \mathrm{COO}\right)_{2} \cdot 3 \mathrm{H}_{2} \mathrm{O}$ (POCh S.A.) was added in appropriate proportions into standard ingredients before the pelletizing during the production of pellets process. Analysis of lead

Table 1 The configuration of treatment groups and lead doses in diet of fish during the 12 months exposure period and the following 12 months exposure or depuration period

\begin{tabular}{|c|c|c|c|c|c|c|c|c|c|c|}
\hline Groups & 1-control & 2 & 2-dep & 3 & 3-dep & 4 & 4-dep & 5 & 5-dep & total \\
\hline $\mathrm{Pb}$ dose in diet $\left(\mathrm{mgkg}^{-1}\right)$ during the first 12 months period & 0.1 & \multicolumn{2}{|l|}{8} & \multicolumn{2}{|l|}{13} & \multicolumn{2}{|l|}{24} & \multicolumn{2}{|l|}{49} & - \\
\hline Number of fish at the beginning $[n]$ (per aquarium) & $30 / 30$ & \multicolumn{2}{|c|}{$30 / 30 / 30$} & \multicolumn{2}{|c|}{$30 / 30 / 30$} & \multicolumn{2}{|c|}{$30 / 30 / 30$} & \multicolumn{2}{|c|}{$30 / 30 / 30$} & 420 \\
\hline Number of fish after 3 months $[n]$ & $26 / 26$ & \multicolumn{2}{|c|}{$28 / 27 / 27$} & \multicolumn{2}{|c|}{$28 / 27 / 27$} & \multicolumn{2}{|c|}{$28 / 27 / 27$} & \multicolumn{2}{|c|}{$28 / 27 / 27$} & 380 \\
\hline Number of fish after 6 months $[n]$ & $20 / 20$ & \multicolumn{2}{|c|}{$24 / 25 / 24$} & \multicolumn{2}{|c|}{$25 / 25 / 24$} & \multicolumn{2}{|c|}{$25 / 25 / 24$} & \multicolumn{2}{|c|}{$25 / 25 / 24$} & 335 \\
\hline Number of fish after 12 months exposure & $14 / 14$ & $13 / 14$ & $15 / 15$ & $14 / 14$ & $15 / 14$ & $14 / 14$ & $15 / 15$ & $13 / 14$ & $15 / 15$ & 257 \\
\hline $\mathrm{Pb}$ dose in diet $\left[\mathrm{mgkg}^{-1}\right]$ during the second 12 months period & 0.1 & 8 & 0.1 & 13 & 0.1 & 24 & 0.1 & 49 & 0.1 & - \\
\hline Number of fish after 15 months $[n]$ & $10 / 10$ & $9 / 10$ & $11 / 11$ & $10 / 10$ & $11 / 10$ & $10 / 10$ & $10 / 11$ & $9 / 10$ & $11 / 11$ & 184 \\
\hline Number of fish after 18 months $[n]$ & $5 / 4$ & $5 / 5$ & $5 / 5$ & $5 / 5$ & $6 / 5$ & $5 / 5$ & $4 / 5$ & $5 / 5$ & $5 / 4$ & 88 \\
\hline
\end{tabular}


concentrations in pellet samples showed the following mean levels: group 1 control, $0.113( \pm 0.03) \mathrm{mgkg}^{-1}$; group 2, 8.07 $( \pm 0.11) \mathrm{mg} \mathrm{kg}^{-1}$; group 3, $13.11( \pm 0.14) \mathrm{mgkg}^{-1}$; group 4, $23.71( \pm 0.18) \mathrm{mg} \mathrm{kg}^{-1}$; and group 5, $48.62( \pm 0.24) \mathrm{mgkg}^{-1} \mathrm{dw}$.

After 12 months of exposure, each experimental group was divided into two groups of fish, one of them were under the same treatment and the second (groups: 2-dep, 3-dep, 4dep, and 5-dep) experienced a depuration period of 12 months and received the control feed until the end of the experiment (Table 1). Throughout the study, fish were fed once daily a ration that amounted to $3 \%$ of their body weight. Feed intake was recorded.

To avoid repeated exposure of fish to the intake of excreted lead from water, aquarium water was changed every 2 weeks. Prior to the first three water changes, water and bottom sediments (excrements and food remains) $\mathrm{Pb}$ concentration was analyzed.

After 12 months of the experiment, fish females reached sexual maturity. Water temperature was raised to $20{ }^{\circ} \mathrm{C}$; after the third day, fish presented spawning behavior. Despite the absence of males, fish ovulated and spawned. Unfertilized eggs were observed in aquariums of all groups.

Fish of each aquarium were individually weighted before exposure and after 12 and 24 months of experiment to study effect of different $\mathrm{Pb}$ dietary doses to body weight.

\section{Tissue sampling}

At $3,6,12,15,18$, and 24 months of the experiment, the following tissues were collected from 8 to 10 randomly harvested fish from each group: kidneys, gills, intestine (divided into anterior and posterior intestine, both without digesta, rinsed with deionized water), muscles, hepatopancreatic gland, skin, scales, and bone tissue from opercula freed from skin. These tissues were frozen until analysis of lead concentration.

$\mathrm{Pb}$ analysis

Prior to determination, tissues (of weight from 1 to $5 \mathrm{~g}$ ) were subjected to preliminary mineralization in presence of $10 \mathrm{ml}$ a 3:1 $v / v$ mixture of nitric acid $(65 \%)$ and perchloric acid (70\%) for about $20 \mathrm{~h}$. The samples were then heated with a Velp 20/26 digester by gradually increasing the temperature to $180^{\circ} \mathrm{C}$ for $6-7 \mathrm{~h}$. The so obtained clear liquid was diluted with deionized water to $10 \mathrm{ml}$ and then assayed for concentration of lead using a Unicam 929 atomic absorption spectrometer (Agemian et al. 1980). The concentrations were read from the standard curve generated using the standards prepared based on atomic absorption standards made at the Office of Weights and Measures in Warsaw. Each sample was assayed in quadruplicate (the average values calculated from replicates were used in statistical analysis). Calibration was repeated every 10 samples. The results were presented in $\mathrm{mg} \mathrm{Pb}$ per $\mathrm{kg}$ wet tissue weight (ww).

Water samples of $5 \mathrm{ml}$ volume, collected from aquaria of different groups, were mineralized in the presence of nitric $\operatorname{acid}(10 \mathrm{ml})$ at $150^{\circ} \mathrm{C}$ for $4 \mathrm{~h}$, and then diluted to $10 \mathrm{ml}$ with deionized water (Ihnat 2003). So prepared samples were analyzed for the level of $\mathrm{Pb}$ in the same way as tissue samples.

Bottom sediment samples were dried in the temperature of $60{ }^{\circ} \mathrm{C}$ for $48 \mathrm{~h}$ (Twyman 2005). Samples of $3 \mathrm{~g} \mathrm{dw}$ were mineralized in the presence of $10 \mathrm{ml}$ nitric acid at room temperature $\left(20^{\circ} \mathrm{C}\right)$ for $20 \mathrm{~h}$ and at $150{ }^{\circ} \mathrm{C}$ for $8 \mathrm{~h}$, and then diluted to $10 \mathrm{ml}$ with deionized water; $\mathrm{Pb}$ level was determined as described above. The results were presented in milligrams $\mathrm{Pb}$ per kilogram dw.

Random pellet samples (weight, $3 \mathrm{~g}$ ) were mineralized in the presence of nitric acid $(10 \mathrm{ml})$ for about $20 \mathrm{~h}$ at room temperature and then for about $7 \mathrm{~h}$ at $150{ }^{\circ} \mathrm{C}$. Finally, the samples were diluted with deionized water to $10 \mathrm{ml}$ and the level of $\mathrm{Pb}$ was determined as described above. The results were presented in milligrams $\mathrm{Pb}$ per kilogram $\mathrm{dw}$. Minimum level of detection for lead was $0.001 \mathrm{mgl}^{-1}$ of water samples and $0.001 \mathrm{mgkg}^{-1}$ of solid samples.

\section{Statistical analysis}

The results were subjected to analysis of variance and the Mann-Whitney test was used to determine significant differences between the experimental and control groups, between the experimental groups (2, 3, 4 and 5) and between the depurated groups (2-dep, 3-dep, 4-dep, 5dep) within each sampling, and between following samplings within the same group. Spearman's correlation coefficients were also calculated to determine significance of the effect of lead dose during exposure on its concentration in individual tissues.

\section{Dynamics of accumulation or depuration}

Because samples were collected at varying time intervals (every 3 or 6 months) to observe the dynamics of accumulation or depuration, monthly increments of lead concentration and monthly lead depuration rate were calculated for appropriate periods by dividing total increment of accumulation calculated for $3,6,12,15,18$, and 24 months of exposure-after which the tissues were sampled, into appropriate number of months for each of these periods. This produced mean monthly increments of $\mathrm{Pb}$ bioaccumulation in tissue in corresponding exposure periods (metal level end of metal accumulation-metal level before exposure)/months of metal exposure. 
Monthly metal depuration rate was calculated by dividing the difference in the mean lead concentration at the end of exposure period and the concentration after the elimination period by the number of depuration months 3,6 , and 12 ; (metal level end of metal accumulation-metal level end of metal depuration)/months of metal depuration. The method for calculating the dynamics of lead accumulation and elimination adapted from Yap et al. (2003).

\section{Results}

The lowest mean body weight $(27.1 \pm 4 \mathrm{~g})$ was observed in fish of group 3 after a 12-month period of $\mathrm{Pb}$ exposure to $13 \mathrm{mg} \mathrm{Pbkg}{ }^{-1}$, while the highest body weight $40.4 \mathrm{~g}$ occurred in the control group. After 24 months of the experiment, mean body weight ranged from $34 \pm 7 \mathrm{~g}$ in fish of group 5-dep to $74 \pm 20 \mathrm{~g}$ in group 2, where fish females were exposed to $8 \mathrm{mg} \mathrm{Pbkg}^{-1}$. Chronic dietary exposure in the range of $8-49 \mathrm{mg} \mathrm{Pb} \mathrm{kg}^{-1}$ resulted in no significant effects on the growth of Prussian carp females (Table 2). The total mortality rate was equal to nine pieces (Table 2).

Lead concentration in water samples collected prior to biweekly water replacement was under the spectrometer limit detection $\left(0.001 \mathrm{mg} \mathrm{PbL}^{-1}\right)$. Mean lead concentration in bottom sediments of aquariums in groups $1-5$ were amounted to $1.54( \pm 0.2), 13.74( \pm 0.8), 24.21( \pm 2.3), 30.88$ $( \pm 3.0)$, and $71.80( \pm 4.4) \mathrm{mg} \mathrm{Pb} \mathrm{kg}^{-1} \mathrm{dw}$, respectively.

Figures 1 and 2 show the lead accumulation levels in studied tissues during the 24-month period of dietary exposure. The tissues that accumulated more $\mathrm{Pb}$ were kidney, bone, and hepatopancreas, reaching values of $7( \pm 0.72), 5$ $( \pm 0.0 .43)$, and $4.5( \pm 0.4) \mathrm{mg} \mathrm{kg}^{-1} \mathrm{ww}$, respectively, after 12 24 months of exposure (Figs. 1a, c and 2d). Statistical significant differences in the lead accumulation levels between groups were observed in all studied tissues $(p<0.05)$ except in the skin (Fig. 2c).

The accumulation of lead was generally the highest at the beginning of exposure, as evidenced by the highest monthly increments of bioaccumulation observed after 3 months of contamination for muscles, hepatopancreatic gland, intestine, and gills (Electronic supplementary material (ESM) Fig. 1S). The dynamics of lead accumulation in the kidney were almost similar throughout the whole exposure period for all doses used. In the case of bone and scales tissues with lower doses of exposure in groups 2, 3, and 4 (and 5 in case of scales) monthly increments of bioaccumulation were highly significant only after 6 months; whereas in group 5, intensive bioaccumulation was already observed during the first 3 months of contamination in the bone (ESM Fig. 2S).

The Spearman's correlation coefficients $\mathrm{R}$ analysis results presented in ESM Table 1S show the significance of the lead dose effect on its accumulation in studied tissues. Figures 3 and 4 present changes of lead concentration in studied tissues of Prussian carp during 12 months dietary exposure to that metal and following 12 months of depuration period. The highest monthly decreases in accumulation were observed in the first 3 months of elimination in kidneys $\left(0.57 \mathrm{mg} \mathrm{kg}^{-1} \mathrm{ww} / \mathrm{month}\right.$ in groups 2-dep and 3$\mathrm{dep})$, in bones ( $0.72 \mathrm{mg} \mathrm{kg}^{-1} \mathrm{ww} /$ month in group 3-dep), in scales $\left(0.46 \mathrm{mg} \mathrm{kg}^{-1}\right.$ ww/month in group 4-dep), and in hepatopancreas $\left(0.33 \mathrm{mg} \mathrm{kg}^{-1} \mathrm{ww} / \mathrm{month}\right.$ in groups 4-dep and 5-dep; ESM Fig 2S). In soft tissues, higher monthly decreases in concentration were observed in the groups previously exposed to higher doses of exposure (4-dep and 5-dep), whereas in hard tissues, such as bones and scales, accumulation rather than elimination was still observed in group 5-dep after the first 3 months (Fig. 4d, e and ESM Fig. 2S). Until the end of the elimination period, statistically significant differences $(p<0.05)$ were observed between the level of lead in the groups subjected to depuration, both in bone tissue and in scales (Fig. 4d and e).

\section{Discussion}

\section{Growth and survival}

No significant differences were observed in fish body weights after 12 and 24 months of experiment (Table 2).

Table 2 Body weight changes after 12 and 24 months of the experiment, and total mortality of fish

\begin{tabular}{|c|c|c|c|c|c|c|c|c|c|c|}
\hline Groups & 1-Control & 2 & 2-dep & 3 & 3-dep & 4 & 4-dep & 5 & 5-dep & total \\
\hline $\begin{array}{l}\text { Mean body weight }[\mathrm{g}] \text { of fish at the } \\
\text { beginning of exposure }\end{array}$ & $19.1 \pm 2 \mathrm{a}$ & $19.7 \pm 2 \mathrm{a}$ & & $20.1 \pm 3 \mathrm{a}$ & & $20.8 \pm 2 \mathrm{a}$ & & $19.9 \pm 2 \mathrm{a}$ & & - \\
\hline $\begin{array}{l}\text { Mean body weight }[\mathrm{g}] \text { of fish after } \\
12 \text { months of exposure }\end{array}$ & $40.4 \pm 6 \mathrm{a}$ & $36.2 \pm 4 \mathrm{a}$ & & $30.9 \pm 4 \mathrm{a}$ & & $27.1 \pm 4 \mathrm{a}$ & & $30.6 \pm 6 \mathrm{a}$ & & - \\
\hline $\begin{array}{l}\text { Mean body weight }[\mathrm{g}] \text { of fish after } \\
24 \text { months of exposure }\end{array}$ & $\begin{array}{r}51.2 \pm \\
8 \mathrm{ab}\end{array}$ & $74 \pm 20 \mathrm{a}$ & $67 \pm 11 \mathrm{a}$ & $44 \pm 5 \mathrm{ab}$ & $\begin{array}{c}65 \pm \\
8 \mathrm{a}\end{array}$ & $48 \pm 12 \mathrm{ab}$ & $51 \pm 19 \mathrm{ab}$ & $53 \pm 13$ a & $34 \pm 7 b$ & - \\
\hline Total mortality [fish] & 2 & 1 & 0 & 1 & 1 & 0 & 2 & 1 & 1 & 9 \\
\hline
\end{tabular}

Different letters indicate statistically significant differences among fish groups at $p<0.05$ (Mann-Whitney $U$ test). Values not sharing letters are significantly different from other treatment values within the same sampling 

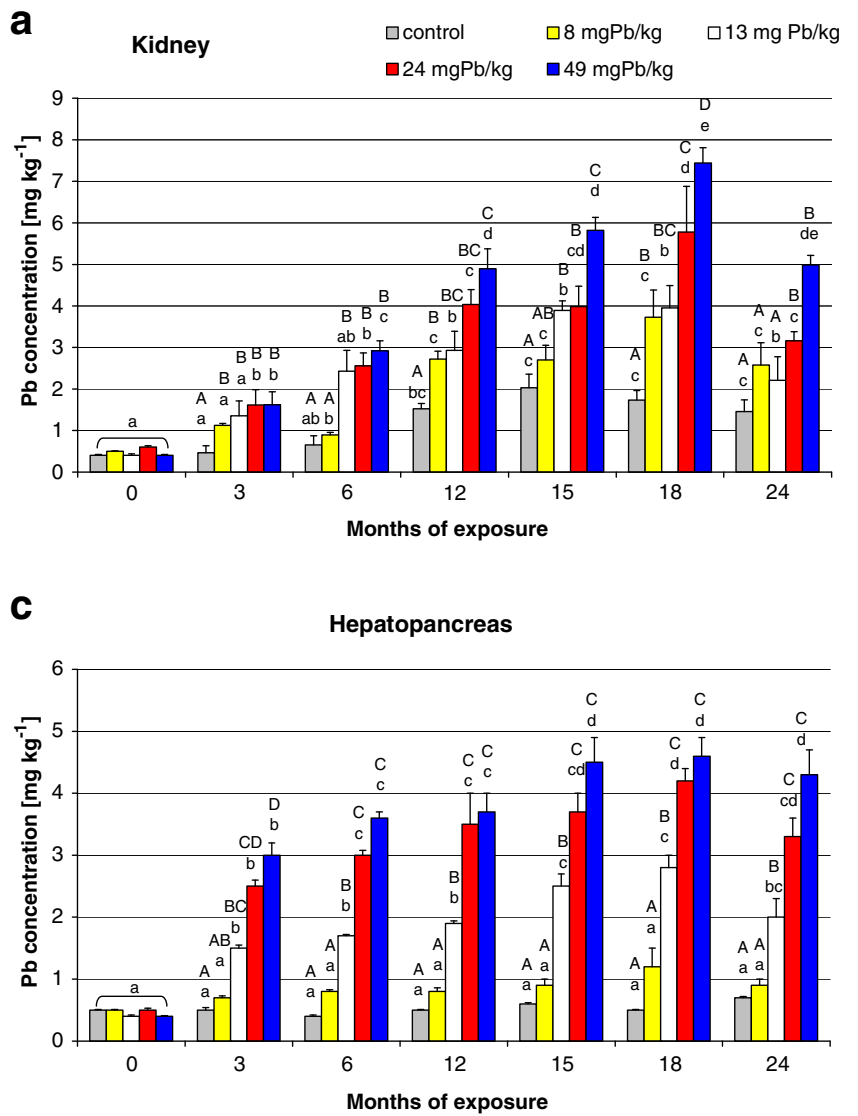

Fig. 1 The comparison of mean lead concentration (milligrams per kilogram tissue wet weight) in the kidney, gills, hepatopancreas, and muscle of Prussian carp females during 24-month period dietary exposure to different levels of lead in the diet. Different letters indicate statistically significant differences among groups at $p<0.05$ (Mann-Whitney $U$ test).

These results are consistent with Alves and Wood (2006), Alves et al. (2006), and Mount et al. (1994) who found no effect of $\mathrm{Pb}$ on growth of rainbow trout. Different results noted Woodward et al. (1994) or Naz et al. (2008) who observed significantly lower body weight increments in fish during the heavy metals exposure. The total mortality rate was equal to nine pieces (Table 2) and was not associated with the dietary $\mathrm{Pb}$ treatments throughout the course of the experiment what is consistent with other dietary studies results (Hodson et al. 1978; Mount et al. 1994; Alves et al. 2006). Some fish species show higher resistance to heavy metals, what may be based either on their ability to accumulate excessive amounts of metals or to exclude heavy metals from tissues. Growth rates and mortality do not appear to be sensitive indicators of dietary $\mathrm{Pb}$ toxicity in Prussian carp.

Accumulation

The only source of $\mathrm{Pb}$ for fish in the present study was the fodder. To avoid the dissolution of $\mathrm{Pb}$ from feces and pellets b

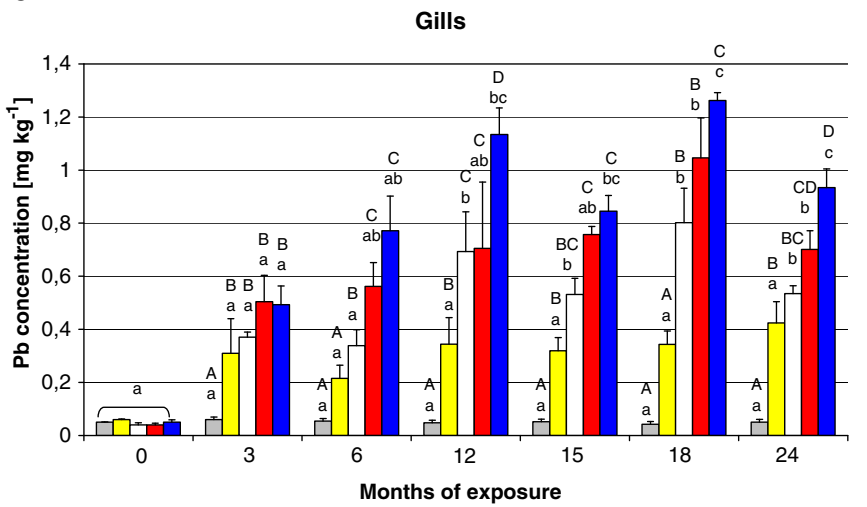

d

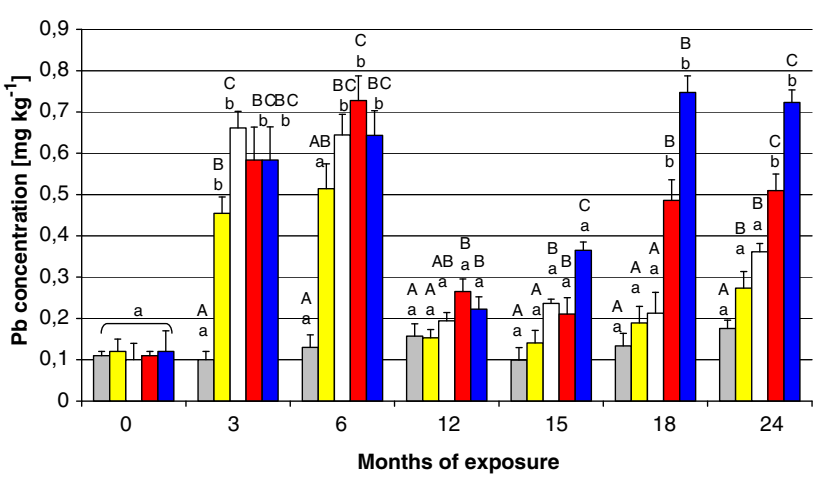

Values not sharing uppercase letters are significantly different from other treatment values within the same sampling. Values not sharing lowercase letters are significantly different from the same treatment between months. Note the different $y$-axis scale

remains, aquarium water was changed every 2 weeks. Water analysis indicated no detectable $\mathrm{Pb}$ level (detection limit, $0.001 \mathrm{mg} \mathrm{PbL}^{-1}$ ) after 2 weeks of feeding fish with the contaminated pellets, despite the $\mathrm{Pb}$ concentrations in bottom sediments in aquariums were enhanced, from 1.5 (in control group) to $78 \mathrm{mg} \mathrm{Pbkg}^{-1} \mathrm{dw}$ (in group 5).

The results obtained suggest that lead bioaccumulation in females of Prussian carp differs in dependence on tissues. The bioaccumulation pattern of lead in different tissues was: kidney $>$ bone $>$ liver $>$ scales $>$ gills $>$ distal intestine $>$ muscle $>$ proximal intestine $>$ skin. Physiological differences in the function and structure of different tissues may affect the bioaccumulation of metals (Kotze 1997). Daily intake of lead ranged from 0.24 to $1.47 \mathrm{mgkg}^{-1} \mathrm{ww}$ (body weight)/day depending on the dose of exposure, so the fish received a total dose of $108-540$ and $216-1,080 \mathrm{mg} \mathrm{Pb} \mathrm{kg}^{-1}$ body weight after 12 and 24 months of exposure, respectively. It is known that a major portion of ingested metals do not accumulate in tissues and are excreted after passing through the digestive system (Glover and Hogstrand 2002). Part of lead, which had been absorbed from the digestive tract into the blood, is distributed 


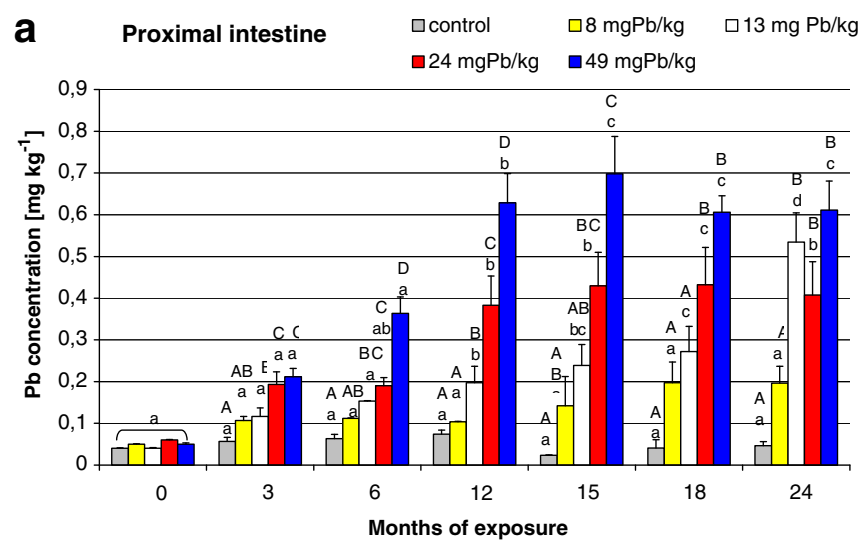

b

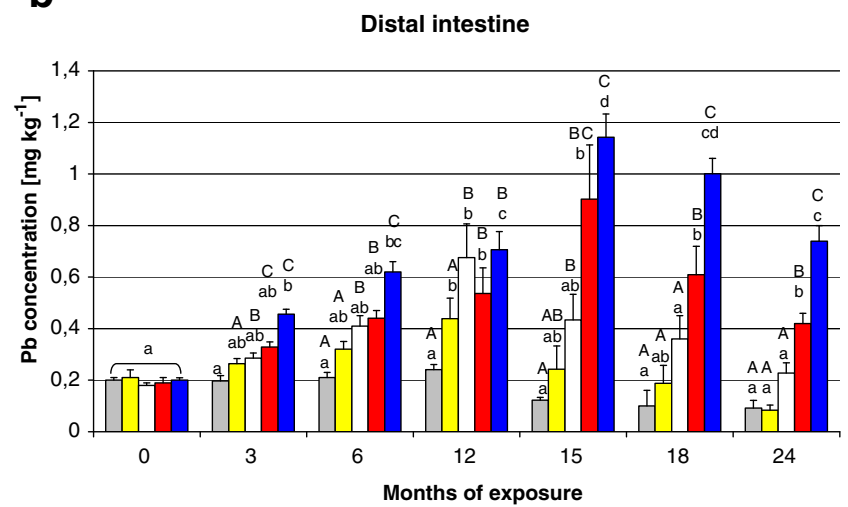

C

Skin

d
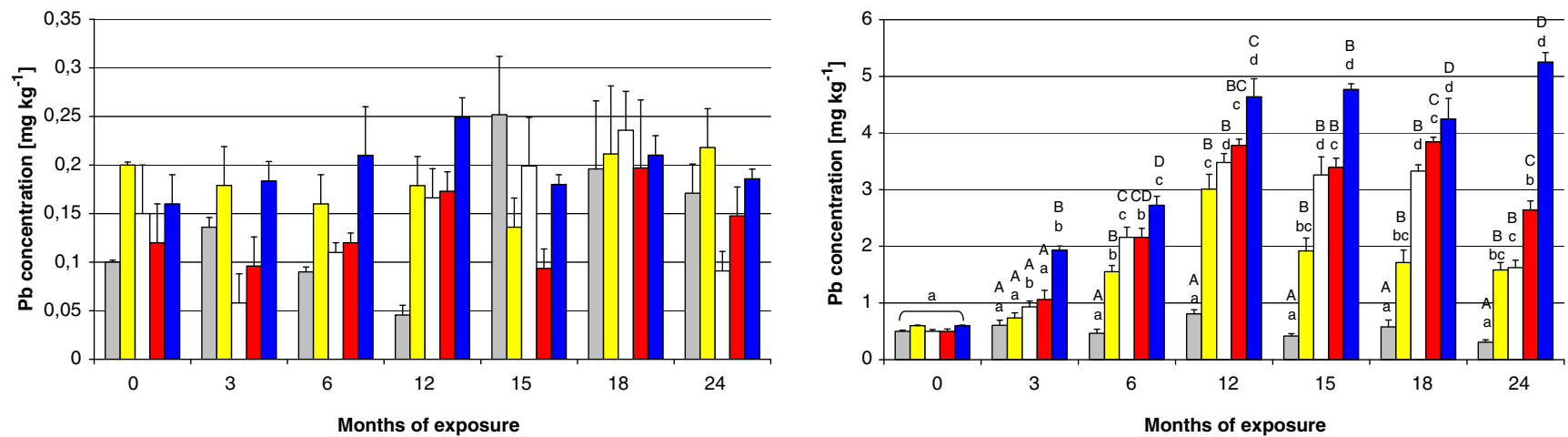

e

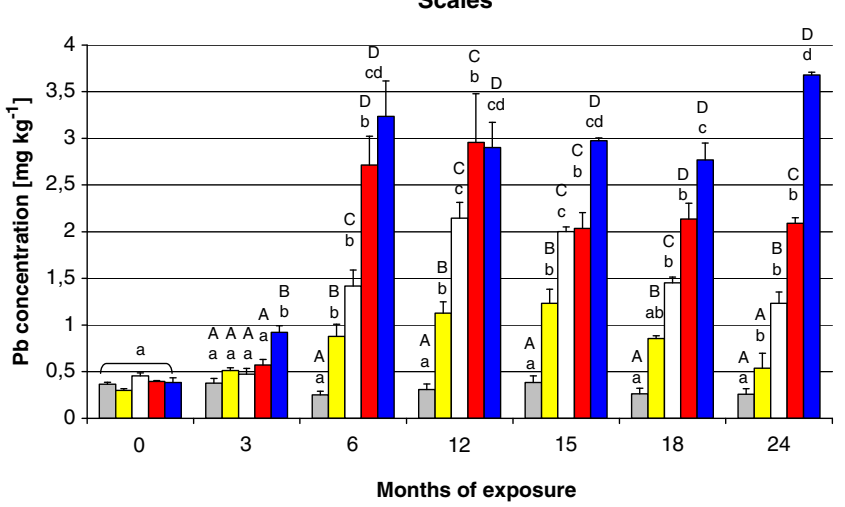

Fig. 2 The comparison of mean lead concentration in the proximal and distal intestine, skin, bone, and scales of Prussian carp females during 24-month period dietary exposure to different levels of lead in the diet.

There were no significant differences in skin tissue. Other details as in legend of Fig. 1

kidney, but more likely the enhanced $\mathrm{Pb}$ level in the kidney was the effect of slow accumulation of $\mathrm{Pb}$ little rates $0.003 \mathrm{mg}$ $\mathrm{Pbkg}^{-1}$ ww (body weight)/day, from control pellets which $\mathrm{Pb}$ concentration was $0.113 \mathrm{mgkg}^{-1} \mathrm{dw}$. The kidney was the only tissue where the increased $\mathrm{Pb}$ level in control group was observed, what indicate that this organ can play the important role in maintain of organism homeostasis.

When observing the process of $\mathrm{Pb}$ accumulation during long-term exposure, it is easy to see the dose dependence. In 

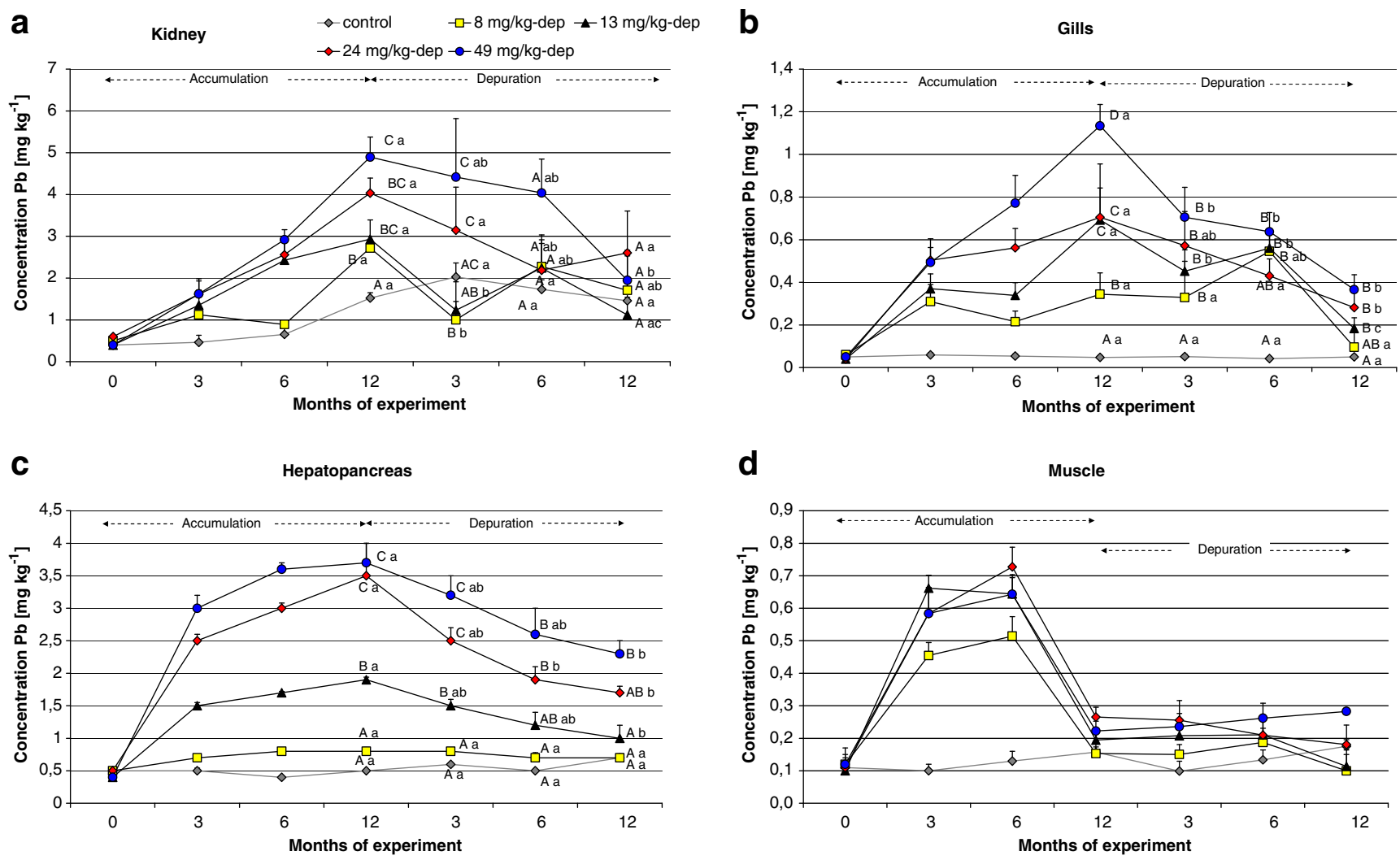

Fig. 3 Changes of $\mathrm{Pb}$ concentration in the kidney, gills, hepatopancreas, and muscle of Prussian carp females during 12 months dietary exposure to that metal and following 12 months depuration periods. Significant differences of lead concentration between groups

all tissues, the highest accumulation resulted from exposure to the highest dietary dose of lead, as confirmed by high correlation coefficients (from 0.61 to 0.96 ) for $\mathrm{Pb}$ concentration and dose in successive periods of the study (ESM Table 1S). Skin is the only tissue which does not reflect the food $\mathrm{Pb}$ contamination and no significant differences occurred in $\mathrm{Pb}$ accumulation between control and treatment groups as well as between following samplings (Fig. 2c and ESM Table 1S).

In all studied tissues except for skin, lead concentration increased steadily with increasing exposure time, and after reaching the maximal level periodically decreased despite continued exposure (Figs. 1 and 2). More or less stable $\mathrm{Pb}$ levels in tissues suggest that fish may be able to regulate lead in organism. This regulation depends on $\mathrm{Pb}$ dose in diet. Lower $\mathrm{Pb}$ exposure reflects lower maximal $\mathrm{Pb}$ concentration levels in tissue. For example the maximal $\mathrm{Pb}$ level of $1.1 \mathrm{mg} \mathrm{kg}^{-1}$ was observed after 15 months of exposure to $8 \mathrm{mg} \mathrm{Pb} \mathrm{kg}^{-1}$ and significant reduction was noted after 24 months in scales. After 12 months of exposure to $13 \mathrm{mg} \mathrm{Pbkg}^{-1}$, the maximal $\mathrm{Pb}$ concentration $2.2 \mathrm{mgkg}^{-1}$ was noted in the tissue and significant decrease after 18 months. During the exposure to higher $\mathrm{Pb}$ doses of 24

(uppercase letters) and in dependence on time depuration (lowercase letters). Different letters mean significant difference $p<0.05$. There were no significant differences in muscle tissue. Note the different $y$ axis scale

and $49 \mathrm{mg} \mathrm{kg}^{-1}$, maximal observed $\mathrm{Pb}$ concentrations were 2.9 and $3.7 \mathrm{mgkg}^{-1}$, respectively, and no significant decreases during the rest of exposure were noted (Fig. 2e). Similar changes in $\mathrm{Pb}$ concentration were observed in bone, kidney, gills, intestine, or hepatopancreas (Figs. 1 and 2). Alves and Wood (2006) noted related $\mathrm{Pb}$ accumulation effect during 42 days dietary $\mathrm{Pb}$ exposure of juvenile rainbow trout, suggesting that some tissues are able to adjust, regulate, and redistribute $\mathrm{Pb}$ to other tissues for detoxification or excretion of $\mathrm{Pb}$. Steady state of $\mathrm{Pb}$ concentration observed in all tissues except skin and muscle after 12 months of $\mathrm{Pb}$ dietary exposure maybe reflects equilibrium between uptake and elimination.

$\mathrm{Pb}$ concentration in muscle tissue was also observed to increase to the maximum level of $0.72( \pm 0.06) \mathrm{mg} \mathrm{kg}^{-1}$ during the first 6 months of exposure to $24 \mathrm{mg} \mathrm{Pb} \mathrm{kg}^{-1}$ (Fig. 1d). Maximum lead levels for certain contaminants in foodstuffs amount to $0.3 \mathrm{mg} \mathrm{kg}^{-1}$ ww (EC 2006), so the concentration values observed during fish exposure in meat exceeded the limit more than two times. Odžak and Zvonaric (1995) noted similar concentration values after 60-day exposure of Dicentrarchus labrax to a dose of $238 \mathrm{mgkg}^{-1}$, as well as a clear relationship between accumulation (in both muscles 

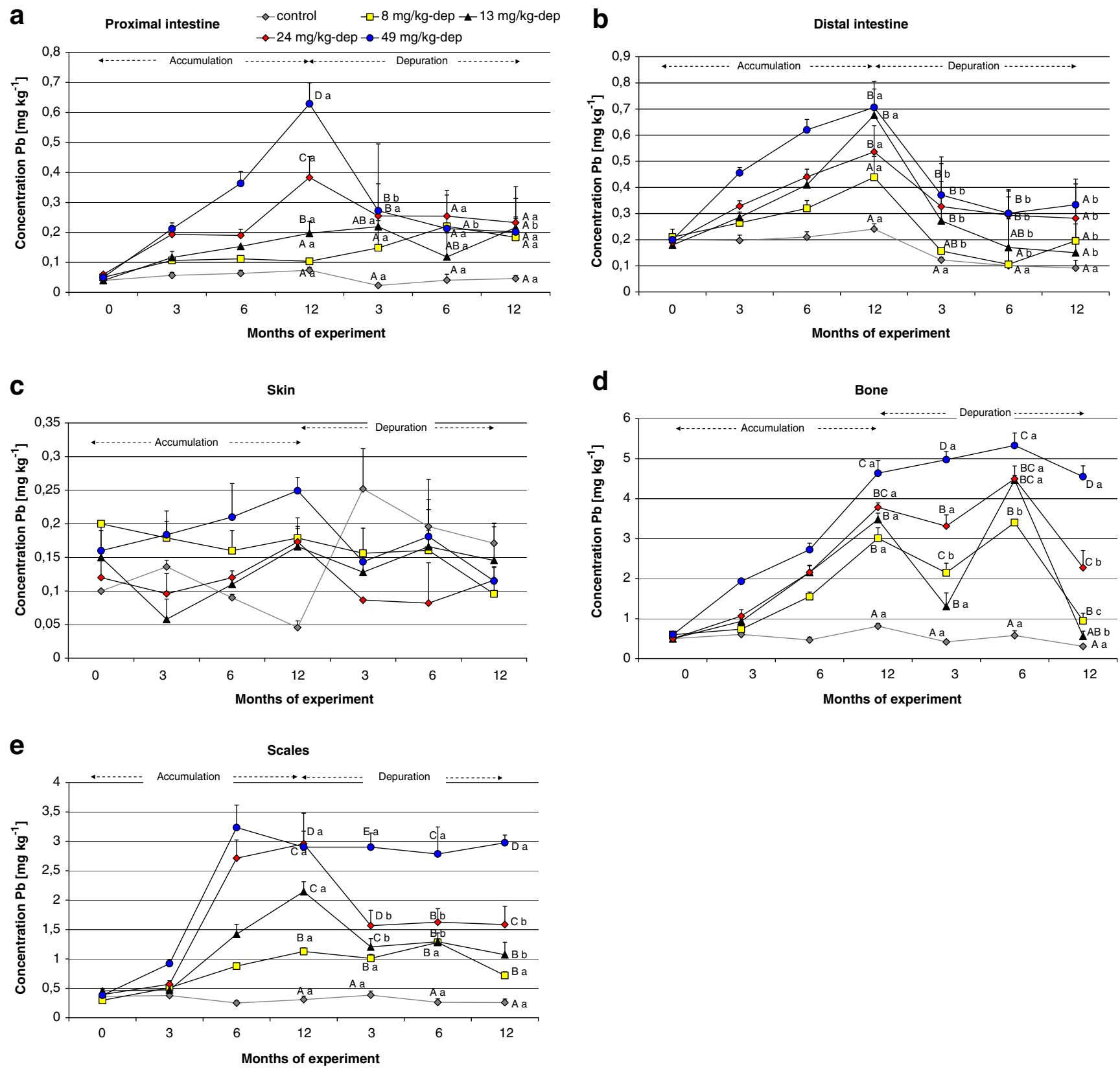

Fig. 4 Changes of $\mathrm{Pb}$ concentration in the proximal and distal intestine, skin, bone, and scales of Prussian carp females during 12 months dietary exposure to that metal and following 12 months depuration

and the liver) and the applied dose of lead exposure. The low accumulation of lead in muscles compared to other piscine tissues is also in agreement with other authors (Bradley and Morris 1986; Wagner and Boman 2003; Jabeen and Chaudhry 2010). A decrease in the level of this metal to the values comparable with control values was observed in muscle tissue between 12 and 15 months of exposure (Fig. 1d). Such depuration of lead from the muscles could be due to fish becoming more resistant in the second year of life, when the development of all body was completed, sexual maturity periods. There were no significant differences in skin tissue. Other details as in legend of Fig. 3

was reached and the immune system was fully developed. Until the end of exposure, no significant increments of $\mathrm{Pb}$ concentration were observed in groups 2 and 3 , and there were no differences in relation to the control group despite the fact that in groups 4 and $5, \mathrm{~Pb}$ concentration increased again to the values similar to those observed in the first year of exposure, i.e., $0.51( \pm 0.04)$ and $0.75( \pm 0.03) \mathrm{mg} \mathrm{kg}^{-1}$, respectively (Fig. 1d). It may be that mature fish remained insensitive to lower doses of lead exposure, but the spawning and gonadal restoration again weakened their resistance to higher doses in 
groups 4 and 5, and Prussian carp responded with reaccumulation of lead in their muscles. Before the next spawning, which occurred at 24 month of the experiment, lead concentration in muscles was not observed to decrease, which excludes the reproductive period as the cause of earlier self-depuration.

For the intestine, higher lead concentrations were observed in the posterior part, where the highest mean concentration of $1.1( \pm 0.09) \mathrm{mg} \mathrm{kg}^{-1}$ occurred after 15 months of exposure to $49 \mathrm{mg} \mathrm{Pbkg}^{-1}$ in group 5 (Fig. 2b); whereas in the anterior part of the digestive tract, the highest mean concentration was $0.7( \pm 0.09) \mathrm{mgkg}^{-1}$ (Fig. 2a). Such distribution of accumulation in the intestine was to be expected because breakdown and digestion take place in the anterior part, whereas the posterior part of intestine in nonpredatory fish is responsible for nutrient absorption, which is why most of the lead was absorbed there. Reverse proportions of lead accumulation in the intestine were reported by Alves and Wood (2006) in trout during 42-day exposure to different combinations of lead and calcium doses. Because of the role it plays in the body, the intestine is particularly at risk of accumulating highest lead concentrations; in contrast, the intestinal levels were comparable to those observed for other soft tissues. This may be due to the protective role of mucus secreted from the intestinal walls, which binds and entraps large amounts of toxic compounds (including lead) from food, thus preventing their absorption by the tissue, which was observed during intestinal perfusion with zinc (Glover and Hogstrand 2002). Crespo et al. (1986) showed that rainbow trout orally administrated with $\mathrm{Pb}((10 \mu \mathrm{g} \mathrm{Pb} / \mathrm{g}$ $\mathrm{dw})$ /fish/day) had morphological alternations of the intestinal brush border, increased mucous cell activity, an increased renewal rate of absorptive cells.

Liver is regarded as an indicator of environmental contamination, because repeatedly demonstrated the existence of dose dependent effect between levels of pollution in the aquatic environment (Hinton and Lauren 1990; Pesch and Kraus 1991; Stentiford et al. 2003), which is confirmed by the constant increments of bioaccumulation and the rapid depuration of considerable portions of accumulated lead in the first period of elimination (ESM Figs. 1S and 2S). The hepatopancreas accumulates relatively higher amounts of $\mathrm{Pb}$ exceeding $4 \mathrm{mg} \mathrm{kg}^{-1}$ body weight during the exposure to 24 and $49 \mathrm{mg} \mathrm{Pbkg}^{-1}$ (Fig. 1c). According to Heath (1991), fish can regulate metal concentration to a certain limit after which bioaccumulation occurs. For the liver of Prussian carp, it seems to be the dietary dose higher than $8 \mathrm{mg} \mathrm{Pbkg}^{-1}$, because no significant changes were noted during 24 months period of the exposure to that dose compared to control group or between the following samplings (Fig. 1c).

Among hard tissues, the highest concentration was found in bones $\left(5.24 \pm 0.17 \mathrm{mg} \mathrm{kg}^{-1}\right.$ at 24 months of exposure in group 5; Fig. 2d). Such a result was to be expected considering that this tissue is the primary target of lead accumulation (Kurey 1991; Rabinovitz 1991; Sorensen 1991). In the groups of fish exposed to lower doses of lead ( 8 and $13 \mathrm{mgkg}^{-1}$; groups 2 and 3, respectively), the accumulation of this metal in the bone in the first year of exposure was twice as high as in the second year, and lead concentrations were indeed observed to decrease in groups 2 and 3, possibly indicating that partial self-depuration from the tissue could occur in the second year of exposure to lower $\mathrm{Pb}$ concentrations (8$13 \mathrm{mgPbkg}^{-1} \mathrm{dw}$ ), despite continued exposure (Fig. 2d). No decreases in lead concentration were observed for higher doses in groups 4 and 5, but it is easily seen that almost all of the accumulated lead was incorporated during the first year of exposure. There were observed no statistical differences in groups between months since the 12th month of experiment (Fig. 2d). Also, analysis of the monthly increments of bioaccumulation in bone tissue (ESM Fig. 1S) and the highly significant coefficients of correlation (ESM Table 1S) indicate that the accumulation is clearly dependent on dose of exposure. While the highest monthly increments of lead are observed after 12 months of exposure in group $2(0.09( \pm 0.001)$ $\mathrm{mgPb} \mathrm{kg}{ }^{-1} \mathrm{ww} / \mathrm{month}$ ) and after 6 months in groups 3 and 4 $\left(0.28( \pm 0.008) \mathrm{mg} \mathrm{Pbkg}^{-1} \mathrm{ww} / \mathrm{month}\right)$, in group 5 they already reach a mean value of $0.44( \pm 0.02) \mathrm{mgkg}^{-1} \mathrm{ww} / \mathrm{month}$ after 3 months (ESM Fig. 1S). This is evidence that the higher the dose of exposure, the quicker the accumulation is in bone tissue. Exactly the same accumulation pattern was observed in scales, where very high coefficients of correlation between $\mathrm{Pb}$ concentration and exposure dose were noted (ESM Table 1S). The higher lead concentrations in hard tissues (bones and scales) than in other tissues were also reported by Rashed (2001) for Nile tilapia from Aswan High Dam Lake in Egypt.

\section{Depuration}

Depuration of accumulated lead from the organs during exposure of 12 months depended mainly on tissue and duration of elimination. Very rapid depuration is observed in soft tissues such as the intestine or muscles, where a relatively quick decrease in $\mathrm{Pb}$ concentration was observed in the groups subjected to elimination (ESM Fig. 2S) and no statistically significant differences in $\mathrm{Pb}$ concentration were found in these groups in relation to the control group (Figs. 3d and 4a, b). In the case of muscles, it is difficult to show whether the decreased $\mathrm{Pb}$ level was due to cessation of exposure, because self-depuration was already observed during exposure. Lead elimination from the kidneys, gills, and hepatopancreas was slightly slower, probably due to their role in the removal of this element from the body (Fig. 3a-c). The elevated concentrations of lead during the 12-month depuration period in these tissues may result from secondary accumulation of the metal released from other 
soft and hard tissues, which managed to accumulate large amounts of lead, and after exposure cessation they responded by releasing accumulated lead into the blood. This is why these tissues still contained lead, although exposure was discontinued a long time before. Effective elimination from the gills and muscles of Nile tilapia was observed after 4-week exposure to lead in water by Al-Nagaawy (2008), who found that elimination from this tissue is different to elimination from the muscle, as well as suggesting that the elimination is related to the earlier dose of exposure.

Very low elimination was observed for scales and bones (Fig. 4d and e) and until the end of the experiment highly significant differences were observed in all the groups in relation to the control group. After occupational exposure, the slow decline in blood lead, a 5- to 19-year half-life, reflects the long skeletal half-life in people (Rabinowitz 1991). Such a low capacity for depuration of hard tissues may be used for monitoring lead contamination of the fish habitat, even a long time after its disappearance. This may make it possible to use these tissues as bioindicators of longterm environmental pollution. Scales collected from live fish can be used for monitoring contamination of fish without killing them, i.e., without loss of ichthyofauna.

\section{Conclusion}

The results obtained from this study indicate that chronic dietary exposure in the range of $8-49 \mathrm{mg} \mathrm{Pbkg}^{-1}$ resulted in no significant effects on the growth or survival of Prussian carp females and these parameters do not appear to be sensitive indicators of dietary $\mathrm{Pb}$ toxicity in this species.

$\mathrm{Pb}$ concentration in all studied tissues except the skin is positively correlated with the metal concentration in the diet. Kidney, bone, and hepatopancreas are the tissues that accumulated more $\mathrm{Pb}$, reaching values of $7( \pm 0.72), 5( \pm 0.0 .43)$, and $4.5( \pm 0.4) \mathrm{mg} \mathrm{kg}^{-1} \mathrm{ww}$, respectively, after 12-24 months of exposure. The accumulation of lead was generally the highest at the beginning of exposure. It is accepted that the concentration of pollutants in the tissues of aquatic animals results from both past and recent pollution of the environment (Ravera et al. 2003). The results of the present study show that a simple analysis of lead concentrations in different tissues may reflect recent environmental contamination, when only soft tissues undergo accumulation; long-term contamination, when all soft and hard tissues undergo accumulation; or contaminants no longer found in the environment, when their presence is only detected in hard tissues such as bones and scales. Researchers interested in studying only long-term contamination may limit themselves to sampling scales to monitor the contamination of fish in a way that poses no threat to their health and lives.
Acknowledgments The research project was supported by Ministry of Science and Higher Education in Poland grant nr N 311012 $31 / 3829$, and approved by the Local Ethics Commission (permission no. $87 / \mathrm{P} / 2005)$

Open Access This article is distributed under the terms of the Creative Commons Attribution License which permits any use, distribution, and reproduction in any medium, provided the original author(s) and the source are credited.

\section{References}

Adeyeye EI, Akinyugha NJ, Fesobi ME, Tenabe VO (1996) Determination of some metals in Clarias gariepinus (Cuvier and Valenciennes), Cyprinus carpio (L) and Oreochromis niloticus fishes in a polyculture freshwater pond and their evviroments. Aquaculture 47:205-214

Agemian H, Sturtevant DP, Austen KD (1980) Simultaneous acid extraction of six trace metals from fish tissue by hot-block digestion and determination by atomic-absorption spectrometry. Analyst 105(1247): 125-130

Al-Nagaawy AM (2008) Accumulation and elimination of copper and lead from $O$. niloticus fingerlings and consequent influence on their tissue residues and some biochemical parameters. 8th International Symposium on Tilapia in Aquaculture. Egypt 1:431-445

Alves LC, Wood CM (2006) The chronic effects of dietary lead in freshwater juvenile rainbow trout (Oncorhynchus mykiss) fed elevated calcium diets. Aquat Toxicol 78:217-232

Alves LC, Glover CN, Wood CM (2006) Dietary Pb accumulation in juvenile freshwater rainbow trout (Oncorhynchus mykiss). Arch Environ Contam Toxicol 51:615-625

Bradley RW, Morris JR (1986) Heavy metals in fish from a series of metal-contaminated lake near Sudbury, Ontario. Water Air Soil Pollut 27:341-354

Boroń A, Szlachciak J, Juchno D, Grabowska A, Jagusztyn B, Porycka K (2011) Karyotype, morphology, and reproduction ability of the Prussian carp, Carassius gibelio (Actinopterygii: Cypriniformes: Cyprinidae), from unisexual and bisexual populations in Poland. Acta Ichthyol Piscat 41(1):19-28

Clearwater SJ, Baskin SJ, Wood CM, MacDonald DG (2000) Gastrointestinal uptake and distribution of copper in rainbow trout. J Exp Biol 203:2455-2466

Crespo S, Nonnotte G, Colin DA, Leray L, Nonnotte L, Aubree A (1986) Morfological and functional alternations induced in trout intestine by dietary cadmium and lead. J Fish Biol 28:69-80

Dallas HF, Day JA (1993) The effect of water quality variables on riverine ecosystems: a review: Water Research Commission Report No. $351-360$

EC (2001) European Commission Regulation no. 466/2001 of 8 March 2001 setting maximum levels for certain contaminants in foodstuffs. Off J Eur Communities 1(77):1-13

EC (2006) European Commission Regulation no. 1881/2006 of 19 December 2006 setting maximum levels for certain contaminants in foodstuffs Official Journal of the European Union L634/5-24

Fan Z, Liu G (1990) The ploidy and reproductive mechanism of crucian carp, C. auratus gibelio. J Fish Biol 36(3):415-419

Farag AM, Woodward DF, Brumbaugh W, Goldstein JN, Mac Connell E, Hogstrand C, Barrows FT (1999) Dietary effects of metalscontaminated invertebrates from the Coeur d'Alene River, Idaho on cutthroat trout. Trans Am Fish Soc 128:578-592

GIOS (2010) The evaluation of rivers and lakes bottom sediments contamination in year2009. http://ekoinfonet.gios.gov.pl/osady/ mapa/Programy/2009.pdf [in Polish] 
Glover CN, Hogstrand C (2002) In vivo characterisation of intestinal zinc uptake in freshwater rainbow trout. J Exp Biol 205:141-150

Heath AG (1991) Water pollution and fish physiology. Lewis, Boca Raton, p 359

Hinton DE, Lauren DJ (1990) Liver structural alterations accompanying chronic toxicity in fishes potential biomarkers of exposure. In: McCarthy JF, Shugart LR (eds) Biomarkers of environmental contamination. Lewis, Boca Raton, pp 17-57

Hodson PV, Blunt BR, Spy DJ (1978) Chronic toxicity of water-borne and dietary lead to rainbow trout (Salmo gairdneri) in Lake Ontario water. Water Res 12:869-878

Ihnat M (2003) Sample preparation for food analysis. In: Mester Z, Sturgeon R (eds) Sample preparation for trace element analysis (Wilson and Wilson's comprehensive analytical chemistry, vol. 41). Elsevier, Amsterdam, pp 765-856, Ch 25

Jabeen F, Chaudhry AS (2010) Monitoring trace metals in different tissues of Cyprinus carpio from the Indus River in Pakistan. Environ Monit Assess 170:645-656

Javed M, Hayat S (1996) Planctonic productivity of river water as a bio-indicator of freshwater contamination by metals. Proc Pak Cong Zool 16:298-383

Journal of Laws (2002) Sorts and concentrations of substances which cause that the spoil is contaminated. Regulation of the Minister of the Environment No 55 item 498. Accessed 16 April 2002 [in Polish]

Journal of Laws (2011) Classification of homogeneous surface water bodies and of environmental quality standards for priority substances. Regulation of the Minister of the Environment No 162 item 1008. Accessed 9 November 2011 [in Polish]

Kotze PJ (1997) Aspects of water quality, metal contamination of sediment and fish in the Oilfants River, Mpumalanga. M.Sc. Thesis, Rand Afr. Univ., South Africa

Kurey WJ (1991) New Madrid refuge contaminants report. U.S. Fish Wild Survey, 6950-H American Parkway, Reynoldsburg, Ohio: 43068, 614-469-6923

Mount DR, Barth AK, Garrison TA, Barten KA, Hockett JR (1994) Dietary and waterborne exposure of rainbow trout (Oncorhynchus mykiss) to copper, cadmium, lead and zinc using a live diet. Environ Toxicol Chem 13:2031-2041

Naz S, Javed M, Hayat S, Abdullah S, Bilal M, Shaukat T (2008) Long term effects of lead $(\mathrm{Pb})$ toxicity on the growth performance, nitrogen conversion ratio and yield of major carps. Pak J Agri Sci 45(3):53-58

Needleman HL, Bellinger D (1991) The health effects of low level exposure to lead. Ann Rev Pub Health 12:111-140

Odžak N, Zvonaric T (1995) Cadmium and lead uptake from food by the fish Dicentrarchus labrax. Wat Sci Tech 32(9):49-55

Pesch HJ, Kraus T (1991) Schwermetalle in leber und umwelt. Postmortal-analytische untersuchungen mittels Zeeman-AAS. 6. Colloquium Atomsprktrometrische Spurenanalytik, 867878
Pourang N (1995) Heavy metal bioaccumulation in different tissues of two fish species with regards to their feeding habits and trophic levels. Environ Monit Assoc 35:207-219

Rabinovitz MB (1991) Toxicokinetics of bone lead. Environ Health Persp 91:33-37

Rabitto IS, Alves Costa JRM, Silva de Assis HC, Pelletier E, Akaishi FM, Anjos A, Randi MAF, Ribeiro O (2005) Effects of dietary $\mathrm{Pb}(\mathrm{II})$ and tributylin an neotroptical fish Hoplias malabarius: histopathological and biochemical findings. Ecotoxicol Environ Saf 60:147-156

Rashed MN (2001) Cadmium and lead levels in fish (Tilapia nilotica) tissues as biological indicator for lake water pollution. Environ Monit Asses 68:75-89

Ravera O, Cenci R, Beon GM, Dantas M, Lodigiani P (2003) Trace element concentrations in freshwater mussels and macrophytes as related to those in their environment. J Limnol 62(1):61-70

Sarnowski P (2003) The effect of metals on yolk sac resorption and growth of starved and fed common carp (Cyprinus carpio) larve. Acta Sc Pol Piscaria 2:227-236

Sorensen EM (1991) Lead. In: Sorensen EM (ed) Metal poisoning in fish. CRC Press, Boca Raton, pp 99-118

Spurný P, Mares J, Hedbavny J, Sukop I (2002) Heavy metal distribution in the ecosystems of the upper course of the Jihlava River. Czech J Anim Sci 47:160-167

Stentiford GD, Longshaw M, Lyons BP, Jones G, Green M, Feist SW (2003) Histopathological biomarkers in estuarine fish species for the assessment of biological effects of contaminants. Mar Environ Res 55(2):137-159

Staniskiene B, Matusevicius P, Budreckiene R, Skibniewska KA (2006) Distribution of heavy metals in tissues of freshwater fish in Lithuania. Pol J Environ Stud 15(4):585-591

Syasina IG, Khlopova AV, Chukhlebova LM (2012) Assessment of the state of the gibel carp Carassius auratus gibelio in the Amur River Basin: heavy-metal and arsenic concentrations and histopathology of internal organs. Arch Environ Contam Toxicol 62(3):465-478

Twyman RM (2005) Wet digestion. In: Sample dissolution for elemental analysis. New York: Elsevier. pp 146-153.

Vincent S, Ambrose T, Selvanayagam M (2002) Impact of cadmium on food utilization of the Indian major carp (Catla catla). J Environ Biol 23:209-212

Wagner A, Boman J (2003) Biomonitoring of trace elements in muscle and liver tissue of freshwater fish. Spectrochimica Acta B 58:2215-2226

Woodward DF, Brumbaugh WG, DeLonay AJ, Little EE, Smith CE (1994) Effects on rainbow trout fry of metals-contaminated diet of benthic invertebrates in the Clark Fork River, Montana. Trans Am Fish Soc 123:51-62

Yap CK, Ismail A, Tan SG, Omar H (2003) Accumulation, depuration and distribution of cadmium and zinc in the green-lipped mussel Perna viridis (Linnaeus) under laboratory conditions. Hydrobiologia 498:151-160 